PAEDAGOGIA ChristianA

2/24 (2009) - ISSN 1505-6872

Renata Jasnos*

Kraków

\title{
Dydaktyczny charakter biblijnej księgi na przykładzie Deuteronomium
}

Księga Powtórzonego Prawa już samym swoim tytułem może sugerować, że jest tekstem prawnym i przez to zniechęcać nieco czytelnika ${ }^{1}$. Chociaż zawiera ona zbiory praw, przepisów i przykazań - w centrum znajduje się zbiór praw (rozdz. 12-26) otoczony przez kompozycje w formie wielkich mów Mojżesza to jednak kodeksem prawa nie jest.

Kontekstem, w jakim redaktor osadził Księgę, jest końcowy czas wędrówki Izraela przez pustynię, po wyjściu z Egiptu i zawarciu przymierza. Sytuuje on Izraelitów w ziemi Moabu, blisko celu wędrówki, czyli Kanaanu. Tu Mojżesz wygłasza swoje mowy i poucza lud przed wejściem do „ziemi obiecanej”. Naucza Bożego prawa, przypomina zawarte przymierze i opiekę Boga. Końcowe rozdziały opisują ostatnie rozporządzenia Mojżesza i jego osłoniętą tajemnicą śmierć. W tym kontekście Księga nabiera charakteru duchowego testamentu.

Chcąc zbadać aspekt dydaktyczny Deuteronomium, trzeba zwrócić uwage na charakter tej biblijnej księgi. Mamy bowiem do czynienia ze starożytnym tekstem religijnym o długiej i złożonej historii redakcji. Dlatego trudno go porównywać z jakimkolwiek współczesnym dokumentem, związanym z procesem wychowawczym. Trzeba raczej najpierw wyszczególnić obecne w Deuteronomium elementy dydaktyczne i dopiero w dalszej analizie określić ramy samego procesu $^{2}$.

* Dr Renata Jasnos, adiunkt w Katedrze Pedagogii Biblijnej, na Wydziale Pedagogicznym Wyższej Szkoły Filozoficzno-Pedagogicznej „Ignatianum” w Krakowie.

${ }^{1}$ Nazwa ta jednak wywodzi się z greckiego przekładu, natomiast oryginalny, hebrajski tytuł brzmi inaczej: debarim „Słowa” albo „Mowy”.

${ }^{2}$ Niektórzy pedagodzy i bibliści próbują wskazać na pedagogię zawartą w różnych księgach biblijnych - zob. J. Bagrowicz, S. Jankowski, „Pan, Bóg twój, wychowuje ciebie” (Pwt 8,5). Studia z pedagogii biblijnej, Toruń 2005; R. Jasnos, Pedagogia Boża w Objawieniu, w: W. Pasierbek 
Na starożytnym Bliskim Wschodzie znane były teksty o charakterze dydaktycznym. Przysłowia ${ }^{3}$ i nauki oraz zbiory instrukcji dotyczące postępowania były cenionym w Egipcie „klasycznym” gatunkiem literackim ${ }^{4}$. Zwykle kierowane były do syna lub ucznia, dotyczyły postępowania, sposobu życia, etykiety, zachowania wśród ludzi w różnych sytuacjach. Zawierały pouczenia, napomnienia, przestrogi, maksymy, filozoficzne rozważania i praktyczne zalecenia dotyczące życia. Pojawiały się w nich często wezwania do nabywania mądrości, słuchania nauczyciela, zachowywania w życiu rad, co miało stanowić podstawę powodzenia i błogosławieństwa ${ }^{5}$.

Deuteronomium wydaje się tekstem, który ma nie tylko charakter świadectwa religijnego, nie tylko służył jako tekst kultyczny ${ }^{6}$, ale również związany był z szeroko rozumianym nauczaniem. Wskazują na to zarówno świadectwa zewnętrzne, jak i przesłanki wewnętrzne.

Księgę Powtórzonego Prawa wywodzi się od Księgi Prawaª do której nawiązują różne księgi biblijne Starego Testamentu. W Deuteronomium mowa jest o nakazie Mojżesza, skierowanym do lewitów, aby przechowywali w arce przymierza Księgę Prawa ze spisanymi przez Mojżesza Bożymi nakazami (Pwt 31, 24-26). Księga Jozuego, przedstawiająca czasy bezpośrednio po śmierci Mojżesza, również odwołuje się do niej (por. Joz 1, 8). Później w czasach królewskich zostaje odnaleziona w świątynnym skarbcu (może w nim zdeponowana, a potem zapomniana) $^{8}$, a nazywana jest zamiennie Księgą Prawa i Księgą Przymierza (2 Krl 22, 2. 8; por. 1 Mch 1, 56-57; Syr 25, 23). Odczytano ją wówczas publicznie w świątyni wobec zgromadzonego ludu (2 Krl 22, 2-8). Druga Księga Kronik, reprezentująca teologię powygnaniową, umieszcza jeszcze w czasach przedwygnaniowego króla Jozafata szeroko zakrojoną akcję nauczania ludu na podstawie Księgi Prawa. Mieli nią kierować wyżsi urzędnicy królewscy, a udział w niej

(red.), Pedagogika ignacjańska wobec wyzwań współczesnego humanizmu. Ignatian Pedagogy for the challenges of humanism today, Kraków 2008, s. 15-32 (wersja ang. s. 33-50).

${ }^{3}$ Por. np. akadyjskie i aramejskie przysłowia i rady. J. B. Pritchard (red.), Ancient Near Eastern Texts Relating to the Old Testament, Princeton ${ }^{3} 1969$ (dalej używam skrótu ANET), s. 425-430.

${ }^{4}$ ANET, s. 412-425: Egipskie instrukcje, nauki; Nauka wezyra Ptah-hotepa; Nauka dla króla Meri-ka-re; Nauka króla Amen-em-heta; Nauka księcia Hor-dedefa; Nauka [pisarza] Ani; Nauka Amen-em-opeta.

${ }^{5}$ Z. Bauer, Literatura staroegipska, w: Historia literatury światowej, t. 1: Starożytność, Kraków 2003, s. 62n. Por. ANET, s. 412-425: Egipskie instrukcje, nauki.

${ }^{6}$ Por. hipoteza G. von Rada: Deuteronomy. A Commentary, Townbridge-Wiltshire 1984, s. 23.

7 Zob. T. Brzegowy, Księgi historyczne Starego Testamentu, Tarnów 1998, s. 232.

${ }^{8}$ Czas odkrycia Księgi Prawa w skarbcu świątynnym datuje się na 622 rok przed Chrystusem. Niezależnie, czy traktuje się tę relację za świadectwo wydarzeń, czy tylko próbę legitymizacji prowadzonej przez króla reformy religijnej, trzeba przyjąć za fakt publiczne zaistnienie Ksieggi Prawa. Por. N. Lohfink, Recent Discussion on 2 Kings 22-23. The State of the Question, w: D. L. Christensen (red.), A Song of Power and the Power of Song. Essays on the Book of Deuteronomy (Sources for Biblical and Theological Study 3), Winona Lake 1993, s. 36-61. 
wziąć wybrani lewici i kapłani. Akcja objęła wszystkie miasta Judy (por. 2 Krn 17, 7-9). Księgi Ezdrasza i Nehemiasza świadczą o tym, że po powrocie z niewoli babilońskiej (V wiek przed Chrystusem) występuje powszechna praktyka nauczania ludu z Księgi Prawa. Księga Nehemiasza (rozdz. 8) opisuje zwyczaj wielogodzinnego czytania i komentowania Księgi dla zgromadzonego na placu ludu, co trwa przez siedem kolejnych dni. Księgi Machabejskie, przedstawiające prześladowania religijne żydów za czasów okupacyjnego władcy, seleucydy Antiocha IV Epifanesa (II wiek przed Chrystusem), opisują akcje niszczenia Ksiąg Prawa (1 Mch 1, zwł. wersety 56-57). Jej posiadanie groziło karą śmierci. Świadczy to wymownie o rozpowszechnieniu Księgi Prawa. Najdłuższy w Psałterzu Psalm 119 jest mądrościową pochwałą prawa i echem zaangażowania w przestrzeganie, interpretowanie prawa, które stało się kluczowym wyznacznikiem religijności żydowskiej: „Twoje ustawy są moimi doradcami. [...] Jestem roztropniejszy od wszystkich, którzy mnie uczą, bo rozmyślam o Twoich napomnieniach. Jestem roztropniejszy od starców, bo zachowuję Twoje postanowienia. Twoje słowo jest lampą dla moich stóp i światłem na mojej ścieżce" (Ps 119, 24b. 99-100. 105).

Trudno dzisiaj określić, na ile obecny kształt Księgi Powtórzonego Prawa oddaje tekst, do którego nawiązują różne księgi biblijne, jednak związek Księgi Prawa z Deuteronomium jest wyraźny, istnieje ciagłość w biblijnej tradycji dotyczącej tego dzieła. Wobec biblijnych świadectw, które wiążą Księgę Prawa z praktyką pouczania ludu o prawie Bożym, warto się przekonać, czy i na ile sama Ksiega Powtórzonego Prawa wskazuje na taki związek. Przedmiotem analizy będą zatem wybrane aspekty tekstu biblijnego, czyli świadectwa wewnętrzne wskazujące na związek Deuteronomium z nauczaniem i wychowaniem.

\section{Związki Deuteronomium z nauczaniem i wychowaniem}

W Księdze Powtórzonego Prawa można odnaleźć wiele elementów usytuowanych na różnym poziomie znaczeniowym tekstu, w jego treści i formie, świadczących o związku Księgi z wychowaniem i nauczaniem.

\section{Motyw nauczania i wychowania}

Księga Powtórzonego Prawa wielokrotnie nawiązuje do zagadnienia nauczania i wychowania. Świadczy o tym między innymi użycie czasowników wskazujących na te procesy. Czasownik lāmad - nauczać (Qal: uczyć się, wprawiać się; Piel: ćwiczyć, wprawiać, uczyć, przyzwyczajać $\left.{ }^{9}\right)$ występuje w Deuteronomium

${ }^{9}$ Por. lāmad, w: F. Brown, S. R. Driver, Ch. A. Briggs, The Brown-Driver-Briggs Hebrew and English Lexicon: with an Appendix containing the Biblical Aramaic, Massachusetts 1996 (dalej używam skrótu BDB), s. 540. 
bardzo często ${ }^{10}$, gdy tymczasem, jak zauważył M. Weinfeld, w innych księgach Pięcioksięgu nie ma go wcale ${ }^{11}$. Zwykle odnosi się on do nauczania, jakie Mojżesz i Bóg kierują do ludu Izraela.

Czasownik jāsar ${ }^{12}$ - wychowywać, dyscyplinować, karać, ćwiczyć, pouczać, wychowywać - występuje w Deuteronomium pięciokrotnie. Dwukrotnie odnosi się do wychowywania przez rodziców (por. 8,$5 ; 21,18$ ) i dwukrotnie do wychowywania człowieka przez Boga (por. 4,$36 ; 8,5$ ).

\section{Literacka forma Deuteronomium}

Nie tylko obecność motywów nauczania i wychowania, ale również literacka forma Deuteronomium wskazuje na jego dydaktyczne cele. Zasadniczy kształt nadają Księdze tak zwane mowy Mojżesza, które stanowią jej redakcyjny szkielet. Bibliści dzielą tę ostatnią Księgę Tory na kilka wielkich mów ${ }^{13}$. Na poszczególne mowy składają się teksty mające formę napomnień, refleksji, lekcji z przeszłości, instrukcji, zachęty do działania. Mojżesz wzywa w nich do przemyślenia i wyciaggnięcia wniosków z minionych wydarzeń, do chodzenia drogą Pana, przestrzegania i wprowadzania w życie Bożych praw, do podjęcia wyboru niosącego konsekwencje dla życia: „kładę przed wami życie i śmierć, błogosławieństwo i przekleństwo. Wybierajcie więc życie, abyście żyli wy i wasze potomstwo" (Pwt 30, 19b) ${ }^{14}$.

Podkreślając „wysoce retoryczną” naturę Deuteronomium ${ }^{15}$, T. Lenchak zwraca uwagę na proces argumentacji stosowany przez mówcę, na figury stylistyczne, i na tak zwaną retoryczną sytuację. Retoryczny charakter znajduje swój wyraz w powtarzających się wezwaniach do adresata Księgi: „słuchaj” $(4,1 ; 5,1$; $6,3.4 ; 9,2 ; 20,3 ; 27,9)$, „pamiętaj” $(5,15 ; 7,18.19 ; 9,7 ; 24,22 ; 25,17)$, „strzeż się bardzo i pilnuj, byś nie zapomniał” $(4,9)$, „poznaj dzisiaj i rozważ w swym sercu" $(4,39)$. To tylko kilka przykładów.

Charakter retoryczny Księgi podkreśla jej wymiar dydaktyczny oraz zamiar oddziaływania na czytelnika.

${ }^{10}$ Por. Pwt 4, 1. 5. 10. 14; 5, 1. 31; 6, 1; 11, 19; 14, 23; 17, 19; 18, 9; 20, 18; 31, 12.13. 19. 22.

${ }^{11}$ M. Weinfeld, Deuteronomy and the Deuteronomic School, Oxford 1972, s. 303.

${ }^{12}$ Por. jāsar, w: BDB, s. 415-416.

${ }^{13}$ A. D. H. Mayes dzieli Księgę na trzy wielkie mowy Mojżesza do Izraela $(1,1-4,43 ; 4,44$ $-28,68 ; 29,1-30,20)$. Rozdz. 31-34 uważa za późniejszy dodatek. A. D. H. Mayes, Deuteronomy, (New Century Bible Commentary), London 1981, s. 5, 110.

${ }^{14}$ Por. J. L. Crenshaw, Education in Ancient Israel, New York-London-Toronto 1998, s. 130 -138 .

${ }^{15}$ T. A. Lenchak, „Choose Life!” A Rhetorical-Critical Investigation of Deuteronomy 28,6930,20, (Analecta Biblica 129), Roma 1993, s. 37. Metodą retoryczną posługiwał się również w analizach Deuteronomium G. Braulik, Die Mittel deuteronomischer Rhetoric: Erhoben aus Deuteronomium 4, 1-40, (Analecta Biblica 68), Rome 1978. 


\section{Tradycje mąrościowe w Deuteronomium}

Tekst Księgi Powtórzonego Prawa jednoznacznie wskazuje na jej związki $z$ literaturą mądrościową ${ }^{16}$. Wezwania kierowane nieustanne do Izraela przypominają formą mądrościowe wezwania ojca do syna, czy mędrca do ucznia ${ }^{17}$. Zwrot „słuchaj”, będący przynagleniem do przyjęcia pouczenia, jest kierowany wielokrotnie do całego Izraela. Te formy są typowe dla Księgi Przysłów, wyrażają one żądanie od ucznia, syna (albo Izraela w Deuteronomium) ciągłej świadomości i pamięci o nauczanych ideałach ${ }^{18}$.

W Księdze Powtórzonego Prawa pojawia się nawet stwierdzenie, że prawo nauczane przez Mojżesza jest dla Izraela „mądrością i umiejętnością”: „Strzeżcie ich (praw i nakazów) i wypełniajcie je, bo one są waszą mądrością i umiejętnością w oczach narodów, które usłyszawszy o tych dekretach powiedzą: «Z pewnością ten wielki naród, to lud mądry i rozumny»" (Pwt 4, 6). Występujące tu: przymiotnik „mądry” hākām i rzeczownik „mądrość” hokmāh, należą do podstawowych pojęć biblijnej literatury mądrościowej ${ }^{19}$.

Mądrościowe tradycje również $\mathrm{w}$ inny sposób przejawiają się $\mathrm{w}$ tekstach Księgi Powtórzonego Prawa. Analizując różne biblijne perykopy, mówiące o kwalifikacjach sędziów w Izraelu, M. Weinfeld zwraca uwagę na różnicę między nimi. W Deuteronomium od sędziego żąda się już nie tyle prawości, dzielności oraz charyzmatu (por. Wj 18; Lb 11), co wiedzy, umiejętności i mądrości ${ }^{20}$. Mojżesz wyznacza na sędziów i przywódców ludu „mężów mądrych, rozumiejących, pełnych wiedzy" (por. 1, 13-17) ${ }^{21}$. Podczas gdy zakaz brania łapówek w wersji Księgi Wyjścia mówi o tym, iż podarek zaślepia oczy dobrze widzących, to w wersji Deuteronomium są to oczy mędrców! (por. Wj 23, 8 - Pwt 16, 19b) ${ }^{22}$.

Księga Powtórzonego Prawa przedstawia ojcowskie i Boże karcenie-wychowanie w słowach bardzo podobnych do Księga Przysłów ${ }^{23}$ i używa tych samych co mądrościowe tradycje kategorii, ukazując wychowawcze oddziaływanie Boga na człowieka. Życiowe doświadczenia, trudności i cierpienia są odczytywane jako przejawy Bożego wychowywania-karcenia: „Uznaj w sercu twoim, że jak wychowuje (jāsar) człowiek swego syna, tak Pan, Bóg twój, wychowuje

${ }^{16}$ Zob. G. Braulik, „Weisheit“ im Buch Deuteronomium, w: tenże (red.), Studien zum Buch Deuteronomium, Stuttgart 1997, s. 225-271; M. Weinfeld, dz. cyt., s. 244-319; R. Jasnos, Teologia Prawa w Deuteronomium, (Studia pedagogiczne 1), Kraków 2001, s. 283-287.

${ }^{17}$ Por. J. W. McKay, Man's Love for God in Deuteronomium and the Father/Teacher - Son/ Pupil Relationship, „Vetus Testamentum” 22 (1972), s. 427.

${ }^{18}$ M. Weinfeld, dz. cyt., s. 299.

${ }^{19}$ W Księdze Przysłów hākām występuje 52 razy, a hokmāh 39 razy. Por. G. Lisowsky, Konkordanz zum Hebraeischen Alten Testament, Stuttgart (1958)1993, s. 491-493.

${ }^{20}$ Por. M. Weinfeld, dz. cyt., s. 244-245.

${ }^{21}$ Tamże, s. 245.

${ }^{22}$ Por. tamże, s. 245.

${ }^{23}$ Tamże, s. 303. 
(jāsar) ciebie" (Pwt 8, 5). Podobne treści zawiera tekst z Księgi Przysłów (por. Prz 3, 11-12). A zatem zarówno w mądrościowej Księdze Przysłów, jak i Deuteronomium wychowanie wiąże się ściśle $\mathrm{z}$ doświadczeniem, karceniem i nauką ${ }^{24}$.

\section{Prawa deuteronomiczne jako instrukcje pouczajace}

Mądrościowe aspekty Księgi Powtórzonego Prawa przejawiają się również w zawartych w niej prawach. C. Carmichael, analizując prawne tradycje w Deuteronomium, zwrócił uwagę na interesującą formę przekazu prawnego, mającą silne znamiona mądrościowego pouczenia. Jest to „forma publicznego przykładu”, występująca kilkakrotnie w Księdze (por. 13, 12; 17, 13; 19, 20; 21, 21) ${ }^{25}$. Cechą szczególną tak sformułowanego prawa jest uzasadnienie: „Cały Izrael, słysząc to, ulęknie się i przestanie czynić to zło pośród siebie” $(13,12)$; „A reszta słysząc to ulęknie się i nie uczyni więcej nic takiego pośród siebie" $(19,20)$. Prawne tradycje przekazywane w takiej formie nastawione są na oddziaływanie społeczne.

Wiele prawnych tekstów zdradza cel dydaktyczny. Wskazują na to tak zwane klauzule motywacyjne praw, czyli dołączone do praw uzasadnienia ${ }^{26}$. Trzeba zauważyć, że znane nam ze świadectw starożytnego Bliskiego Wschodu zbiory prawne nie posiadają klauzul motywacyjnych ${ }^{27}$, natomiast mają takie klauzule instrukcje służące do pouczania ${ }^{28}$. Treść klauzul dołączonych do praw w Deuteronomium świadczy o ich dydaktycznym charakterze. Niektóre z nich odwołują się do założonego idealnego porządku: „u ciebie nie powinno być biednych” (15, 4 , por. z bardziej rzeczywistym 15,11 ). Wydaje się zatem, że celem praw deuteronomicznych jest przedstawienie programu społecznego i religijnego, a nie prawnych norm.

Może wydawać się również dziwne uzasadnienie nakłaniające do przestrzegania praw tak brzmiące: „żeby ci było dobrze i synom twoim po tobie” $(12,25$. 28). Ta motywacja rozciąga się na przyszłość tak daleką, że sięga życia potomków, co nie wydaje się realnym uzasadnieniem praktykowanego prawa. Prawdopodobne wydaje się natomiast, że prawa deuteronomiczne były nośnikiem dydaktycznych celów autora mądrościowego - takim celem mogło być pouczenie o tym, że posiadanie ziemi obiecanej oraz przyszły los narodu wiąże się ściśle z przestrzeganiem Bożych nakazów.

${ }^{24}$ Por. R. Jasnos, Pedagogia Boża, s. 15, 19.

${ }^{25}$ C. Carmichael, The Laws of Deuteronomy, London 1974, s. 44.

${ }^{26}$ B. Gemser wskazuje aż 61 takich klauzul w Deuteronomium. Por. B. Gemser, The Importance of the Motive Clause in Old Testament, (Vetus Testamentum Suppl 1; 1955), s. 50-66. C. Carmichael podkreśla wielość klauzul w Deuteronomium w odróżnieniu od nielicznych klauzul w tzw. kodeksie przymierza zawartym w Księdze Wyjścia. Wprawdzie w Deuteronomium są też prawa bez takiej klauzuli, ale niektóre prawa posiadają nawet dwa uzasadnienia. Por. C. Carmichael, dz. cyt., s. 37.

${ }^{27}$ R. de Vaux, Ancient Israel. Its Life and Institutions, London 1988, s. 149.

${ }^{28}$ R. Jasnos, Teologia Prawa, s. 106-108. 
Na fakt, że Księga Powtórzonego Prawa posiada cele dydaktyczne, wskazuje również inna cecha opracowania jej treści. W Deuteronomium widać tendencję do powtarzania i nawarstwiania się materiału. C. Carmichael analizuje przykład tekstów dotyczących składania ofiar, które są wielokrotnie wymieniane w rozdziale 12, ale w różnym zestawieniu i ilości. Autor tłumacząc, że analiza źródeł czy warstw tekstu nie przynosi zadowalających rezultatów, stwierdza, że tekst powstał jako instrukcja ze skłonnością do powtarzania tego samego materiału, ale powtarzania go na różny sposób. Zatem lista wymienianych w instrukcji ofiar sugeruje, że jest to raczej język nauczyciela niż kompetentny projekt czy szkic prawnika $^{29}$.

Innym rodzajem powtórzeń w tekstach prawnych są konstrukcje o charakterze paralelizmu synonimicznego ${ }^{30}$, czyli przywoływanie treści na różny sposób, innymi słowami - typowe dla biblijnych tekstów poetyckich, prorockich i dydaktycznych: ,Jeśli będzie pośród ciebie ubogi któryś z twych braci [...] nie okażesz twardego serca wobec niego, ani nie zamkniesz swej ręki przed ubogim swym bratem" $(15,7$; por. 12,$30 ; 14,24.26)$.

Carmichael zauważa ponadto pewną dynamikę, która się pojawia w prawach zawartych w Deuteronomium. Gdy przedstawiony jest pozytywny nakaz, to łączy się on z negatywnym zakazem lub ostrzeżeniem, natomiast gdy prawo rozpoczyna negatywnie sformułowany zakaz, wówczas łączy się on z pozytywnym nakazem $^{31}$. C. Carmichael dowodzi, że takie pozytywno-negatywne sformułowania należą do kręgu pouczeń mądrościowych. Określa on taką formę jako instrukcję w szerokim znaczeniu i uważa, iż taki sposób formułowania prawa wskazuje na jego bliskie pokrewieństwo z radą mędrca ${ }^{32}$. Według G. von Rada tzw. deuteronomiczny kodeks (rozdz. 12-26) to w istocie stare materiały prawne, rozwinięte w formie kazań ${ }^{33}$.

Przeprowadzone przez C. Carmichaela analizy praw w Deuteronomium skłaniają do stwierdzenia, że mają one raczej charakter mądrościowych instrukcji i pouczeń, niż norm będących podstawą dla izraelskiego sądownictwa ${ }^{34}$. A zatem analiza treści i form literackich Księgi Powtórzonego Prawa - zarówno mów Mojżesza, jak i kodeksu prawnego - prowadzi do wniosku, że ma ona wybitnie pouczający charakter. Upodabnia ją to do literatury mądrościowej, a wiele elementów jest bezpośrednio z niej zaczerpniętych.

${ }^{29}$ C. Carmichael, dz. cyt., s. 37.

30 Tamże, s. 47.

31 Tamże, s. 42-43. Przykład 1) 12, 2-4: pozytywny rozkaz - „zniszczycie... miejsca, gdzie narody... służyły swoim bogom”, łączy się z negatywnym zakazem - ,nie postąpicie tak z waszym Bogiem”. Przykład 2) 13, 4-5: zakaz (negatywny) - „nie usłuchasz słów tego proroka”, łączy się z pozytywnym nakazem - „za Bogiem swoim, Jahwe pójdziesz...”.

32 Tamże, s. 42-43.

${ }^{33}$ G. von Rad, Deuteronomium, w: G. A. Buttrick, T. S. Kepler, J. Knox (red.), The Interpreter's Dictionary of the Bible. An Illustrated Encyclopedia, New York-Nashvile 1957, s. 835.

${ }^{34}$ C. Carmichael, dz. cyt., s. 35-52. 


\section{Dydaktyka w Deuteronomium}

Księga Powtórzonego Prawa posiada niewątpliwie cechy retoryczne, mądrościowe i dydaktyczne. Można zatem przypuszczać, że w tekście powinny pojawić się treści przynajmniej pośrednio świadczące o zawartym w Księdze procesie nauczania czy szeroko rozumianego wychowania. Myślę, że nie będzie anachronizmem używanie w kontekście analizy biblijnej księgi współczesnych pojęć z zakresu dydaktyki, takich jak: cele, treści, zasady, metody czy formy wychowania i kształcenia. Współczesna dydaktyka bowiem nie stworzyła procesu nauczania, ale nazwała czynniki występujące w każdym świadomym procesie nauczania czy wychowania.

\section{Strony procesu wychowawczego}

W Księdze Powtórzonego Prawa nie łatwo jednoznacznie określić strony procesu wychowawczego i to nie dlatego, że są nieznane, ale z powodu ich złożoności. Jeżeli chodzi o osobę wychowawcy-nauczyciela, to trzeba rozpatrzyć kwestię na kilku poziomach. Literackim mówcą i nauczycielem w Deuteronomium jest Mojżesz. To on jest wymieniany wielokrotnie $\mathrm{z}$ imienia (1, 1. 3. 5; 4, 41. 44. 45. 46.; 5, 1; itd.), on wygłasza mowy, odwołuje się do zleconej mu przez Boga misji nauczaniu ludu $(4,5 ; 5,31 ; 6,1)$. Ale przecież Mojżesz jest ,jedynie" pośrednikiem, przedstawicielem Boga, czyli właściwego Wychowawcy narodu. Chociaż Mojżesz naucza Bożego prawa, to sam Bóg wychowuje (o czym tekst mówi wprost, używając czasownika jāsar 8, 5; por. 4, 36). Zasadne jest jednak pytanie o to, kto był redaktorem Deuteronomium i twórcą deuteronomicznego nauczania. Niektórzy egzegeci opowiadają się za hipotezą o kapłanach nauczających lud prawa ${ }^{35}$. Bardziej prawdopodobna wydaje się jednak hipoteza M. Weinfelda o pisarzach-mędrcach, urzędnikach królewskich, sprawujących zarazem urząd nauczycieli w Izraelu ${ }^{36}$. To oni stają się organizatorami nauczania ludu prawa $i$ oni stoją za analizowanym przeze mnie procesem dydaktycznym Księgi.

Określenie odbiorców, czyli podmiotów deuteronomicznego nauczania-wychowania nie jest łatwiejsze. Na pierwszy ,rzut oka” są nimi Izraelici obozujący w ziemi Moabu przed wejściem do ziemi obiecanej. Ale z lektury Księgi wynika, że zajęcie ziemi nie tylko się dokonało, ale także jej późniejsza utrata stała się rzeczywistością. W Księdze są teksty mówiące w szczegółach o podboju i utracie ziemi, o rozproszeniu wśród narodów (por. 30, 1-2a. 5a; 4, 25-31). Zatem „przyszła" niewola babilońska jest już dla adresatów Księgi nabytym doświadczeniem. „Drugim” adresatem będą więc Izraelici w sytuacji ponownego objęcia w po-

${ }^{35}$ G. von Rad, Deuteronomy. A Commentary, s. 23-24.

${ }^{36}$ M. Weinfeld, dz. cyt., s. 55, 158-161. Na temat redaktorów Deuteronomium zob. szerszą dyskusję: R. Jasnos, Teologia Prawa, s. 174-181. 
siadanie ziemi, już po powrocie z niewoli. „Trzeci” adresat jest określony przez retoryczny charakter Deuteronomium. Parenetyczny charakter samej Księgi Powtórzonego Prawa sprawia, że ostatecznym adresatem staje się każdorazowy jej czytelnik. Dlatego R. Polzin pisze o Deuteronomium, że jest ona „otwarciem ram historii i panoramiczną synopsą"37.

\section{Cele}

Cele dydaktyczne Deuteronomium są wyrażone w sposób pośredni w mowach Mojżesza. Postulowane zmiany u adresatów, wyrażone w kategoriach nawyków i postaw, nie są trudne do odczytania w kontekście mów Mojżesza i dotyczą przyjęcia Bożego prawa oraz postępowania drogą Boga. Mowy skupiają się na wzbudzeniu i ukształtowaniu postawy adresata wobec Boga, wyrażonej czasownikami: „słuchać głosu Boga”, „strzec Jego prawa i zamieniać w czyn Jego przykazania”, „przylgnąc do Boga”, „,kochać Go” (por. 10, 12; 11, 1. 13. 22;

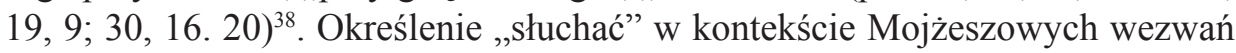
wiąże się postawą otwartości, posłuszeństwa ${ }^{39}$. Słuchanie powinno zamieniać się w coraz większe zaangażowanie ${ }^{40}$. Celem optymalizującym tego procesu wychowawczego jest rozwinięcie zaangażowania adresata, co wyrażone jest między innymi zwrotem ,z całego serca i z całej duszy” (por. 4, 29; 6, 5; 10, 12; 11, 13. 18; $13,4 ; 26,16 ; 30,2.6 .10)^{41}$. Równocześnie pojawia się także cel minimalizujący, jakim jest całkowite wyeliminowanie kultu obcych bogów z życia Izraelitów: „Zniszczycie doszczętnie wszystkie miejsca, gdzie narody, których wy pozbawicie dziedzictwa, służyły swoim bogom: na górach wysokich, na wzgórzach i pod każdym drzewem zielonym" $(12,2)^{42}$.

${ }^{37}$ Por. R. Polzin, Reporting Speech in the Book of Deuteronomy: Toward a Compositional Analysis of the Deuteronomic History, w: D. L. Christensen (red.), dz. cyt., s. 72.

${ }^{38}$ Ta postawa wiąże się z wyborem Izraela przez Boga i wejściem z nim w przymierze: „Będziecie dla Niego ludem, a On będzie dla was Bogiem" (Pwt 29, 12). Słowa te są typową dla biblijnych tekstów formułą przymierza. Por. A. Rofé, The Covenant in the Land of Moab (Deuteronomy 28: 69-30: 20): Historico-Literary, Comparative, and Formcritical Considerations, w: D. L. Christensen (red.), dz. cyt., s. 279.

${ }^{39} \mathrm{O}$ znaczeniu ,słuchania” w Biblii w kontekście wychowania pisze S. Jankowski, Wychowanie w literaturze mqdrościowej, w: J. Bagrowicz, S. Jankowski, dz. cyt., s. 175.

${ }^{40} \mathrm{Na}$ temat dynamiki zaangażowania wychowanka w biblijnym procesie edukacyjnym zob. N. Shupak, Learning Methods In Ancien Izrael, ,Vetus Testamentum” 53 (2003), nr 3, s. 416-426.

${ }^{41} \mathrm{Na}$ temat zwrotu ,z całego twego serca i z całej twej duszy” zob. R. Jasnos, Teologia Prawa, S. 259 .

${ }^{42}$ Księga Powtórzonego Prawa zdaje się świadectwem przełomowego zwrotu w zmaganiu się wiary w jednego Boga z pełną folkloru wiarą politeistyczną. Większość Izraelitów, traktując Boga JHWH jako bóstwo narodowe, nie widziała sprzeczności w jednoczesnym czczeniu innych bóstw. Deuteronomium świadczy o istniejącej grupie ,ekskluzywistów”, jak nazywa ich D. Patrick, którzy lojalni tylko wobec JHWH przyjęli misję nawrócenia rodaków na tę radykalną drogę. Por. D. Patrick, The Rhetoric of Collective Responsibility in Deuteronomic Law, w: D. P. Wright, D. N. Freedman, A. Hurvitz (red.), Pomegranates and Golden Bells. Studies in Biblical, Jewish, and Near Eastern Ritual, Law, and Literature in Honour of Jakob Milgrom, Winona Lake 1995, s. 435. 


\section{Treści}

Do treści kształcenia, zawartych i wyrażonych w Deuteronomium, zaliczyć można $\mathrm{z}$ jednej strony tak zwane prawo ${ }^{43}$, które przyswoić sobie powinien adresat jako instrukcje, pouczenia i zasady postępowania w relacji do Boga i do człowieka, a z drugiej strony wydarzenia z historii Izraela, które adresat powinien zrozumieć i zapamiętać (por. 1, 6-3, 17; 5, 2-33; 8, 2-3. 14-16; 9, 7-10, 11). Należą do nich zawarcie przymierza na Horebie (Synaju), jako czas nawiązania szczególnej relacji z Bogiem, wędrówka przez pustynię jako czas próby i opieki ze strony Boga, a także wydarzenia ,przyszłe” niewoli babilońskiej i możliwości powrotu z niej po nawróceniu się do $\operatorname{Boga}(4,25-31 ; 30,1-10)$ : ,jeśli wrócisz do Pana, Boga swego, [...] odwróci też i Pan, Bóg twój, twoje wygnanie i zlituje się nad tobą. Zgromadzi cię na nowo spośród wszystkich narodów, gdzie cię Pan, Bóg twój, rozproszył [...] Sprowadzi cię Pan, Bóg twój, do ziemi, którą przodkowie twoi otrzymali w posiadanie, abyś ją odzyskał; uczyni cię szczęśliwym i rozmnoży cię bardziej niż twoich przodków" (Pwt 30, 2-3. 5).

\section{Zasady}

Wśród zasad kształcenia i wychowywania w Księdze Powtórzonego Prawa, traktowanej jako tekst o charakterze dydaktycznym, dostrzec można związek wiedzy z praktyką oraz operatywność wiedzy. Wpajane prawo ma być praktykowane i właśnie po to jest nauczane. Mówca, pouczając na przykład o zasadach kultu, zapowiada co winien uczynić adresat, kiedy przyjdzie do kapłana z pierwocinami płodów i wyjaśnia, jakie znaczenie będzie miała ta ofiara: „Gdy wejdziesz do kraju, który ci daje Pan, Bóg twój [...] weźmiesz pierwociny wszelkich ziemiopłodów. [...] Pójdziesz do urzędującego wtedy kapłana i powiesz mu: Oświadczam dziś Panu, Bogu twojemu, że zaszedłem do ziemi, o której Pan przysiagł przodkom, że nam ją da. Kapłan weźmie z twoich rąk koszyk i położy go przed ołtarzem Pana, Boga twego" (26, 1-4). Wykonywane czynności kultyczne będa miały zarazem charakter przypomnienia i utrwalania świadomości Bożych dzieł (zasada trwałości wiedzy).

Tymczasem pytania mówcy, nawet te retoryczne, świadczą o przestrzeganej zasadzie świadomego i aktywnego udziału adresata: „Czy słyszał jakiś naród głos Boży z ognia, jak ty...? Czy usiłował Bóg przyjść i wybrać sobie jeden naród spośród innych narodów przez doświadczenia, znaki, cuda i wojny [...] w Egipcie na twoich oczach?" $(4,33-35)$.

Gdy mówca odwołuje się do niedalekiej przeszłości, do wymownych doświadczeń, można mówić o zasadzie poglądowości. Wspólne „spojrzenie wstecz” na minione wydarzenia jest podstawą do wyciągnięcia wniosków, do zrozumienia podstawowej dla przyszłego postępowania adresatów prawdy: „Prowadziłem

${ }^{43}$ Prawne tradycje Księgi Powtórzonego Prawa zawarte są w rozdziałach 12-26. 
was przez czterdzieści lat po pustyni; a nie podarły się na was szaty ani obuwie na waszych nogach [...] abyście poznali, że Ja, Pan, jestem waszym Bogiem" (29, 4-5). Ponadto można zauważyć, iż zapowiedzi „przyszłości” są kierowane już post factum do tych, którzy już doświadczyli „zapowiadanych” wydarzeń, ich przywołanie jest zaś rodzajem refleksji nad doświadczaną rzeczywistością (zasada poglądowości): ,Wtedy przyszłe pokolenia [...] powiedzą: [...] Czemuż to Pan tak uczynił tej ziemi? Dlaczego ten żar gniewu? I odpowiedzą: Bo opuścili przymierze Pana, Boga ich przodków, zawarte z nimi, kiedy ich wyprowadził z ziemi egipskiej" (29, 21-24).

Pogłębiona refleksja nad minionymi wydarzeniami prowadzi do wyciagnięcia wniosków operatywnych dla teraźniejszości i przyszłości adresata (związek wiedzy z praktyka): „Wy wiecie, z kim mieszkaliśmy w Egipcie [...] Widzieliśmy ich obrzydliwości, ich posagi z drzewa i kamienia... Niech nie będzie między wami żadnego mężczyzny ani kobiety, ani rodu, ani pokolenia, którego by serce się odwróciło od Pana, Boga waszego, idąc służyć bogom tych narodów" (29, 15-17).

\section{Metody}

Metodą kształcenia i wychowania stało się powtarzanie, napominanie i pouczanie. Sama Księga Powtórzonego Prawa odczytywana, komentowana, „,brana do serca" (por. 11, 18; 32, 46) i ,zapamiętywana” stała się środkiem, narzędziem kształcenia i „pomocą dydaktyczną”. Księga wielokrotnie powtarzająca nauki i napomnienia, wyjaśnienia i nakazy, zawierająca retoryczne zwroty (,słuchaj”, „weźcie sobie do serca”, „dobrze to przemyślcie”), oddziaływała w sposób wychowawczy na czytelnika.

Księga Deuteronomium sama nakazuje, aby ojciec uczył syna prawa, aby mówił o nim o różnych porach dnia, niezależnie od miejsca przebywania, a nawet, by je wypisywał na odrzwiach i bramach: „Słuchaj, Izraelu... Niech pozostaną w twym sercu te słowa, które ja ci dziś nakazuję. Wpoisz je twoim synom, będziesz o nich mówił przebywając w domu, w czasie podróży, kładąc się spać i wstając ze snu. Przywiążesz je do twojej ręki jako znak. Niech one ci będą ozdoba przed oczami. Wypisz je na odrzwiach swojego domu i na twoich bramach" (Pwt 6, 4. 6-9).

Tak pojęta memoryzacja prowadziła nie tylko do zapamiętania, ale także do powstawania tradycji oraz komentowania i rozwijania prawa, do jego zadomowienia się w życiu i w społeczności Izraela. Wiemy, że Księgę Prawa odczytywano po powrocie z niewoli babilońskiej w zgromadzeniach liturgicznych. Żydzi w późniejszej tradycji rozwinęli praktyczne metody „stosowania” słów Deuteronomium. Tefilin (filakterie) ${ }^{44}$ stały się dosłownym wyrazem retorycznych

${ }^{44}$ Tefilin (filakterie) służą do modlitwy. Tefilin to z języka aramejskiego „ozdoba”. Nazwą tą określa się skórzane pudełka zawierające fragmenty z Księgi Wyjścia i Księgi Powtórzonego Pra- 
wezwań „niech ci będą ozdobą między oczami” i ,przywiążesz je do swojej ręki jako znak".

\section{Formy}

Można również określić złożone formy wychowania, do których nawiązuje Księga Powtórzonego Prawa. Bardzo ważna dla nauczania deuteronomicznego jest wspólnota religijno-narodowa. Księga zawiera, jako istotną cechę swego nauczania, odwołania do idei narodu wybranego ${ }^{45}$ i związanego z Bogiem przymierzem. Liczne prawa świadczą że nauczanie dokonuje się we wspólnocie i kierowane jest do członka społeczności o charakterze narodowym i religijnym (por. forma publicznego przykładu - z klauzulą: „Cały Izrael, słysząc to, ulęknie się i przestanie czynić to zło pośród siebie” [13, 12].

Bardzo interesujące, w kontekście rozważanych form wychowania, jest literackie zjawisko zmienności adresata zachodzące w mowach Deuteronomium. Charakterystyczne jest $\mathrm{w}$ nich przechodzenie między liczbą pojedynczą a mnogą, między „ty” i „wy”. Interpretacje tego zjawiska nie zostały rozwiązane w ramach analizy procesu redakcyjnego i nawarstwień tekstu ${ }^{46}$. Dlatego też opinie biblistów wskazują raczej na walor językowy i literacki tej dynamiki ${ }^{47}$. Ta zmienność określa styl autora, który ma swój cel literacki - szczególnej aktywizacji słuchaczy. Wielu egzegetów jest zdania, że adres w drugiej osobie liczby pojedynczej wskazuje na Izraela jako całość, natomiast adres w drugiej osobie liczby mnogiej kierowany jest do poszczególnych osób wspólnoty i ma charakter bardziej bezpośredni ${ }^{48}$. Przyjmując te opinie, można stwierdzić, że występująca w Deuteronomium zmienność adresata, jako zabieg retoryczny, świadczy o tym, iż występuje tu zarówno wychowanie indywidualne, jak i wychowanie poprzez wspólnotę.

\section{Zakończenie}

Deuteronomium jako tekst religijny jest wyrazem tradycji, której opracowywanie trwało przez kilka stuleci. Twórcy tej tradycji oraz dzieła literackiego,

wa. Za pomocą rzemieni mężczyźni mocowali je na lewym przedramieniu i na czole. W ten sposób słowa Deuteronomium były zastosowane dosłownie. Mezuza jest pudełkiem z ustępem z Deuteronomium, mocowanym z prawej strony na odrzwiach w domach Żydów. Tu również występuje dosłowne zastosowanie deuteronomicznego nauczania. Por. A. Unterman, Encyklopedia tradycji i legend żydowskich, Warszawa 1994, s. 285-286, 178.

${ }^{45}$ Idea narodu wybranego przez Jahwe, jako szczególną i cenną własność, została rozwinięta właśnie w Deuteronomium (por. 7, 6; 14, 2; 26, 18).

${ }^{46}$ Por. T. A. Lenchak, dz. cyt., s. 12-13.

${ }^{47} \mathrm{Na}$ temat gramatycznego aspektu adresu zob. R. Jasnos, „Kładę dziś przed toba”... (Pwt 30,15). Adresaci Tory w Księdze Powtórzonego Prawa, Rocznik Sekcji Pedagogiki Religijnej WSFP „Ignatianum”, Kraków 2002, s. 111-115.

${ }^{48}$ T. A. Lenchak, dz. cyt., s. 16. i 13. 
jakim jest Księga Powtórzonego Prawa, w przedstawieniu dynamicznej relacji pomiędzy Bogiem a Izraelem posłużyli się modelem zaczerpniętym ze świata starożytnej pedagogiki. Świadczą o tym motywy nauczania i wychowania obecne w Deuteronomium, użycie czasowników lāmad i jāsar oraz specyficzna forma literacka księgi, która jest oparta na mowach Mojżesza, a przy tym odznacza się wyjątkowo retorycznym charakterem. Ponadto na Deuteronomium składają się tradycje naznaczone nurtem mądrościowym, a przepisy prawne tracą wymiar jurydyczny i stają się rodzajem instrukcji, w których dominuje element pouczenia.

Te związki Księgi Powtórzonego Prawa z nauczaniem pozwalają wyodrębnić i naszkicować elementy procesu nauczania oraz szeroko rozumianego wychowania. Kwestia wychowawcy-nauczyciela jest szczególnie złożona. Ujmując rzecz od strony literackiej, nauczycielem jest Mojżesz, natomiast ostatecznym wychowawcą narodu jest Bóg. Tymczasem tym, który wprowadził treści dydaktyczne do tekstu, jest redaktor Księgi, wyłaniający się z kręgów pisarzy-mędrców. Odbiorca, czyli adresatem treści nauczania, to jest instrukcji, pouczeń i zasad postępowania wobec Boga oraz człowieka, jest Izrael - naród posiadający określoną historię, ale równocześnie skierowany ku przyszłości. Historia stanowi również treść Mojżeszowego nauczania. Adresat jest wezwany poprzez zabiegi natury retorycznej do aktywnego i świadomego udziału w procesie wychowawczym. Ma mu w tym pomagać metoda kształcenia i wychowania, której istota tkwi w powtarzaniu i rozważaniu nauczanych treści w różnych porach dnia. Przypominanie wydarzeń i ich „realizacja”, na przykład osadzenie w kulcie, stanowią przejaw związku wiedzy z praktyką oraz wyraz operatywności samej wiedzy. Przekazywanie zdobytej wiedzy synom świadczy także o operatywności wiedzy i jej związku z życiem.

To wszystko dokonuje się wewnątrz religijno-narodowej wspólnoty, jako wychowanie poprzez wspólnotę, ale także wychowanie indywidualne. Wyjątkowość tego procesu wychowawczego polega na tym, że ostatecznym odniesieniem wszystkich pouczeń i ostatecznym „Wychowawcą” jest sam Bóg. Natomiast sama Księga Powtórzonego Prawa nieustannie odczytywana, komentowana, i „brana do serca" staje się kluczowym środkiem i pomocą dydaktyczną procesu wychowawczego. Jednocześnie jest jego świadectwem.

\section{The didactic character of a biblical book on the example of Deuteronomy} (Summary)

Deuteronomy as a biblical text expresses tradition which was being developed for a few centuries. Its creators used a model taken from the world of ancient pedagogy to present the dynamic relation between God and Israel. Deuteronomy consists of the traditions coming from the wisdom current, and legal articles comprised in the book lose their jurisdictional dimension and become some kind of instructions, where the element 
of caution is prevailing. The relationship between Deuteronomy and teaching allows to distinguish and outline the elements of the process of teaching or widely understood process of education.

The addressee is called by means of rhetoric to active and conscious participation in educational process. The method of education whose essence lies in repeating and reflecting upon the contents taught on various times of the day is supposed to help. Reminding of the events and their "realization", for example setting them in the cult, manifests the relationship between knowledge and practice as well as the expression of efficiency of knowledge itself. Passing the knowledge acquired to your sons also signifies the efficiency of knowledge and its connection with life. All of this takes place inside the religious and national community, as education through community, but also individual education. The uniqueness of this educational process is that the ultimate reference of all cautions and the ultimate „,educator” is God Himself. And Deuteronomy itself incessantly interpreted, commented and "taken to hart", becomes the key means and didactic aid for educational process. At the same time, it is testimony to this process. 